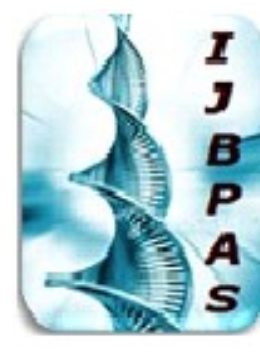

International Journal of Biology, Pharmacy and Allied Sciences (IJBPAS) 'A Bridge Betusen Caboratory and Q Quder'

\title{
Www.iibpas.com
}

\section{EVALUATION OF NUTRITIONAL VALUE AND ETHNOMEDICINAL USE OF Opuntia elatior MILL: A REVIEW}

\section{PATEL $V^{1}$, GIRI SG ${ }^{2 *}$, PATEL $V^{3}$, PANDYA $^{4}$ AND GURKHA $\mathbf{R}^{5}$}

1, 3, 4, 5: M. Sc. Microbiology, Parul Institute of Applied Scinces, Parul University, Limbda, waghodia Road Vadodara 391760, Gujarat, India

2: Assistant Professor, Parul Institute of Applied Scinces, Parul University, Limbda, waghodia Road Vadodara 391760, Gujarat, India

*Corresponding Author: E Mail: suchetaghorai@gmail.com

Received $26^{\text {th }}$ Nov. 2019; Revised $9^{\text {th }}$ Dec. 2019; Accepted $12^{\text {th }}$ Feb. 2020; Available online $1^{\text {st }}$ June 2020 https://doi.org/10.31032/IJBPAS/2020/9.6.5091

\begin{abstract}
Nowadays people are very concerned about their health, it has been observed allopathy medicines that have many side effects and the alternative of allopathy is Ayurveda and Ayurveda is a heart and soul of India. People started using medicinal plants stated in Ayurveda in order to avoid the adverse effects of allopathic medicines. There are several plants with medicinal properties but mostly people are not well aware about these plants. Opuntia elatior Mill, commonly called Prickly Pear, Nagphani and hathlo-thore is a genus of cetacean. Several plants have medicinal properties in their parts or itself with the purpose of exploring the active ingredients in it, that can be used in production of new drugs. Due to the remarkable biological activity of Opuntia and its constituents, that can be utilized for developing medicines. These plants are also studies for its nutritional and medicinal value. Many pharmacological studies have demonstrated the ability of the fruit shows, Anti-inflammatory, Antibacterial, Antidiabetic, Antidiarrheal and Antispermatogenic. The fruit were preliminary evaluated by estimation of proximate analysis. The aim of study is to review different nutritional value and Ethanomedicinal use of Opuntia elatior Mill.
\end{abstract}

Keywords: Opuntia elatior Mill, Ayurveda, Anti-inflammatory, Antibacterial, Antidiabetic, Antidiarrheal and Antispermatogenic 


\section{INTRODUCTION}

Phytopharmaceuticals product have served as a major source of drugs for centuries and today about half of the pharmaceuticals products are derived from natural products. Plants with solid bioactive constituents have as of late increased a lot of enthusiasm for improving in general prosperity just as for avoidance and treatment of different diseases. The nearness of conceivably dynamic constituents in cactus pear and their multifunctional activity, make cactus pear perfect contender for the creation of wellbeing advancing nourishments and Pharmacologicals. It is particularly isolated from plants to control diseases, the continuous use of these techniques has led to the discovery of more than half of the modern pharmaceuticals [1]. The counteraction of infection and clinical experts exceptionally incredible interest for improving by and large life. Right now, sorts of wild fruits and vegetables have been perceived as significant wellsprings of nutraceuticals. One of the commonly used herb is fruit of Opuntia elatior Mill. having an oval shaped, an elongated Berry, consisting of a thick pericarp with a number of clefts of small princkles, dark reddish in color with a luscious sweet pulp intermixed with many small hard seeds [2]. The plant
Opuntia elatior Mill. belongs to the family cactaceae, which is reported to have 130 genera, and 1500 species [3]. Cacti have been considered as a cheap, alternate source of food suitable for humans and feed for animals and are cultivated as Ornamental crops [4]. Opuntia species have been used by humans for different purposes since thousands of years and it is one of the most diverse and widely distributed genus in America, and India, but the highest richness of wild species are found in Mexico, as at least 126 species with different degrees of domestication have been observed [5]. It is mostly found in Saurashtra region of Gujarat and some other dry lands. They are commonly known as prickly pears, because of their edible fruits and they have been accidentally introduced into India and other countries by early European travellers, who used to carry these plants for use as vegetable to prevent scurvy during their long voyages [6]. This cactus fruits are used for treatment of inflammation, pain and detoxification agents for snake bites in China. These fruits are used in diet as an essential element to fulfill the requirements of nutrients which cannot synthesize in human body. The biochemical components present in the food are classified into six major groups are 
protein, fats, carbohydrates, minerals, vitamins and rough age. The amount of the essential nutrients required differ by age and the state of the body [7]. High levels of some of chemical compounds like betalains, taurine, calcium, magnesium, and antioxidants present are very useful [8].

\section{Morphology and Taxonomical} distribution: -

Opuntia elatior Mill plant is scrubby, $34 \mathrm{~m}$ height. Leaves $67 \mathrm{~mm}$ long, recurved and reddish at the tops. Joints are $1830 \mathrm{~cm}$ size in height by $1018 \mathrm{~cm}$ in width, obovate, thin and dull bluish green color. Little territory spike bearing is around $45 \mathrm{~cm}$ and increment up to $10 \mathrm{~cm}$, rather thin straight prickles which are, dim and obscure aside from when very youthful, the biggest of around $35 \mathrm{~cm}$ long. Blossom is $5 \mathrm{~cm}$ over, yellow or orange in shading. The perianth pivot, with the external fragments short, praise, intense, they are red in the middle, yellow at the edges, and the internal spatulate is intense. Stamens are somewhat shorter than the perianth. Style surpasses the stamens; marks of shame six in numbers. Berry pyriform are, bearing tufts of glochidia and a couple of prickles, rosy purple shading when ready [2].

Opuntia elatior Mill which belong to Domain Eukaryota, Kingdom is Plantae, Phylum is Spermatophyta, Subphylum is
Angiospermae,Class is Dicotyledonae, Order is Caryophyllales, Family is Cactaceae, Genus is Opuntia, Species is Opuntiaelatior. Opuntiaficus-indica which belong to Domain Eukaryota, Kingdom is Plantae, Phylum is Spermatophyta, Subphylum is Angiospermae, Class is Dicotyledonae, Order is Caryophyllales, Family is Cactaceae, Genus is Opuntia, Species is Opuntiaficus-indica.

Opuntiaficus-indica grows mainly in the region with water scarcity. The plant contains the different parts, which includes seed, cladodes, skin fruit and pulp [9]. It is a succulent, xerophytic, spiny or spineless plant with multiple beneficial uses.

\section{Different Properties of Opuntia ficus Indica}

Traditional use:-Opuntia ficus indicia have many uses for the medical treatment. It is used for treatment of burns, wound edema and indigestion. From other researches, it is found that its alcoholic concentrates have anti-inflammatory, hypoglycemic, antibacterial activities. Besides, the thorny pear cactus stem has been utilized generally to treat diabetics [10].

Phytochemical composition: Opuntia ficus indica is the potential source of useful phytochemicals like ascorbic acid, amino 
acid, vitamins, flavonoids, alkaloids, carotenoids and fibers $[\mathbf{1 1}, \mathbf{1 2}]$.

Pharmacological activities: It is also consumed due to its pharmacological activities such as antimicrobial activity, antioxidant, anti-cancer, anti-inflammatory, antiulcer and neuroprotective activity. Therefore, besides its medicinal property, it is also being consumed as a food and beverages and is prepared as juice, jam, frozen fruit and spray dried powder [13].

\section{Nutritional Value}

Human body requires the proper nutrition for growth, reproduction and other metabolic activities in body such as food intake, absorption, assimilation, biosynthesis, and excretion. Appropriate eating regimen gives the quality and sustenance that people need to forestall sickness, Organic production of food incorporates cultural, biological, and mechanical practices that foster cycling of assets, advancing environmental parity and monitoring biodiversity [14]. Opuntia pads are studied in several stages of its maturity. The nutritional content varies by the maturity life. Some studies have defined the nutritional elements for fresh young pads and older maturity stage pads. Meanwhile, opuntia prickly pad is also a source of different nutrients such as pectin, mucilage, and minerals. Other studies have defined as the high level of amino acid into it. Essential nutrient includes vitamins, minerals, proteins, fat, carbohydrates. Opuntia contains different types of vitamins such as Vitamin A is help in cellular repair and maintenance. Nervous system development and also help in reproduction, bone growth and antioxidant activity [15]. Vitamin B1 is help in macro nutrient metabolism and Neuronal function in humans. Vitamin B2 helps in antibody and red blood cell formation and has an ocular function. Vitamin B6 helps in fat and protein metabolism, DNA and RNA synthesis, Electrolyte balance and neuronal function. Vitamin B3 helps in production of sex hormone. Vitamin $\mathrm{C}$ helps in wound healing and corticosteroid synthesis [16]. Vitamin E is help in synthesis of hemegroup.Lipid fraction of fruit and seed of cactus contain fat-soluble vitamin $\mathrm{E}$ or tocopherols [17]. Some of the minerals necessary for health are as follows: -Calcium and Manganese Both are important for bone strengthening. Also involved in blood clotting. Iron is primarily involved in the transfer of oxygen from the lungs to tissues. (News Medical) Magnesium Supports in healthy immune system. Zinc is essential for synthesizing protein, DNA, and RNA in human body. Sodium helps to maintain fluid volume outside of the cells. 
Potassium prevents the excess rise of blood pressure with increased sodium intake [18].

\section{Medicinal Value}

Cactus have been used in treating several diseases. Every part of plant has their own functional properties.

Phylloclade is used in anthrax, abscess, wound and abdominal pain. Leaves are used in Body ache, inflammation and heat. Thorns are used in Diphtheria. Fruit is used in burning sensation in the stomach, Asthma, cough, inflammation and ophthalmia, Gonorrhea, laxative, sterility, respiratory disorders, Ulcer. Stem is used in Asthma, joint pain, swelling and muscular pain. Flowers are used in Hemorrhoids, measles [19].

Also, it used in modern nutrition and medicine. Widely used as folk medicines, used to improve platelet function, promote wound healing and reduced cholesterol levels. The natural extract is a useful for alcohol hangover and the plant's gel like sap is often used as a hair conditioner.

It is to note that the ingestion of Opuntia prickly pears also improves the platelet function and haemostatic balance, thus contributing to prevent the atherosclerotic risk [20].

\section{CONCLUSION}

It can be concluded that, fruit of opuntia elator Mill. has rich nutritional values and it has too many medicinal properties. Most of world's population still depends upon these kinds of traditional remedies. The intake of proper nutrients helps increase your daily metabolism, improves the strength of your born and increases blood flow to brain. Opuntia elatior Mill. With its multi faceted properties is occupying prominent position in herbal medicinal system. Almost all parts of this plant are used in different therapeutic purpose. Further studies need to be carried out on cactus in order to confirm its medicinal uses and also explore other potential pharmacological activities. This plant could serve as source of bioactive constituents for future pharmacological studies and drug development. The review of literature revealed the presence of many bioactive constituents in cactus, which could be responsible for various nutritional, medicinal and pharmacological uses of cactus.

\section{REFERENCE}

[1] Thirupati K, Kumar SS, Raju VS, Ravikumar B, Krishna DR, Krishna Mohan G (2008). A Review of medicinal plants of the genus Cordia: their chemistry and 
pharmacological uses. Journal of Natural Products, 8(1), 1-10.

[2] Kirtikar, K.R. and Basu, B.D (2014). Indian Medicinal Plants, $2^{\text {nd }}$ edition, International Book Distributors, Dehradun, India. II,1997, 1173-117813- Ennouri M, Ammar I, Khemakhem B, Attia H. Chemical composition and antibacterial activity of Opuntia ficus indica F. inermis (cactus pear) Flowers. J Med. Food. 17:908-914.

[3] Chhavi Sharma, Sangeeta Rani, Bijander Kumar, Arvind Kumar and Vinit Raj (2015). Plant Opuntia dillenii: A Review on Its Traditional Uses, Phytochemical and Pharmacological Properties. Ecronicon Pharmaceutical Science. $<1(1): 29$ 43.

[4] Estrada Luna A.A, Martinez Hernandez J.D.J, Torres Torres M.E, Chable Moreno F(2008). In vitro micropropagation of the ornamental prickly pear cactus Opuntia lanigera Slam Dyck and effects of sprayed GA3 after transplantation to ex vitro conditions. Sci Hortic.117: 378 -385.

[5] J. A. Reyes-Agüero and J. R. Aguirre Rivera (2011).
Agrobiodiver- sity of cactus pear (Opuntia, Cactaceae) in the meridional highlands plateau of Mexico, Journal of Natural Resources and Development, Vol. 1, pp. 18.

[6] Wang P. Z (1998). Chinese medicine surgery. Ancient Chinese medicine Press. Pp: 164183.

[7] Johanna D (2006). Nutritional requirements and dietary assessment. In: Longo et al., editors. Harrisons Principles of internal medicine. $18^{\text {th }}$ ed. Vol. 1. pp. 172-181. Chapter 73

[8] Jana S (2012). Nutraceutical and functional properties of cactus pear and its utilization for food application. Journal of Engineering Research and Studies.3(2):60-66

[9] Griffith MP (2004). The origins of an important cactus crop, Opuntia ficus-indica (Cactaceae, new molecular evidence, AM J Bot. 2004; 91:1915-1921.

[10] Saenz C (2005). Processing techniques an alternative for cactus pear (Opuntia spp) fruit and cladodes, Journal of arid environment. 46: 209-225.

[11] Ennouri M, Ammar I, Khemakhem B, Attia H (2014). Chemical composition and 
antibacterial activity of Opuntia ficus indica F. inermis (cactus pear) Flowers. J Med. Food.17: 908-914.

[12] Yasmeen R, Hashmi AS, Anjum AA, Saeed S, Muhammad K (2012). Antibacterial activity of indigenous herbal extracts against urease producing bacteria. J. Anim. Plant. Sci. 22:416-419.

[13] Salim N, Abdelwahab C, Rabah C, Ahcene B (2009). Chemical composition of Opuntia ficus-indica (1.) fruit, African journal of Biotechnology. 898:1623-1624.

[14] Williams CM (2002). Nutritional quality of organic food: Shades of grey or shades of green? Proc. Nutr. Soc. 61: 1924.

[15] Bender DA (2003). Nutritional Biochemistry of the Vitamins. 2nd ed. United Kingdom: Cambridge University Press; 470.

[16] Hammond N, Wang Y, Dimachkie MM, Barohn RJ (2013). Nutritional Neuropathies. Neurologic Clinics, 31(2):477-489. DOI: 10.1016/j.ncl.2013.02.002

[17] Anon (2006). Field botany at Williams College. Ed. Williams College: USA.
[18] Feugang JM, Konarski P, Zou D, Stintzing FC, Zou C (2006). Nutritional and medicinal use of cactus pear (Opuntia spp.) cladodes and fruits. Front Biosci., 11: 257489.

[19] Prajapati, S., \& Ayurved, G (2016). Opuntia elatior Mill (Nagaphani): A Review on its Ethnobotany, Phytochemical and Pharmacological Properties. Annals of Ayurvedic Medicine, 4(3), 106116.

[20] R. M. Wolfram, H. Kritz, Y. Efthimiou, J. Stomatopoulos, and H. Sinzinger (2002). "Effect of prickly pear (Opuntia robusta) on glucose- and lipid-metabolism in non-diabetics with hyperlipidemia-a pilot study," Wiener Klinische Wochenschrift, vol. 114, no. $19-20$, pp. $840-846$. 